\title{
Prevalence and Associated Factors of Enuresis in Turkish Children
}

\author{
Cuneyt Ozden, Ozdem L. Ozdal, Serkan Altinova, Ibrahim Oguzulgen, Guvenc Urgancioglu, Ali \\ Memis
}

Department of Urology, Numune Education and Research Hospital, Ankara, Turkey

\begin{abstract}
Objective: Enuresis, which is frequently diagnosed amongst schoolchildren, is an important psychosocial problem for both parents and children. In the present study we aimed to determine the prevalence and associated factors of enuresis in Turkish children and to identify common methods for its management.

Materials and Methods: A cross sectional epidemiological study was performed among primary school children living in Ankara, Turkey. A self-administered questionnaire was prepared for this study and distributed to the parents of 1,500 schoolchildren whom aged 6-12 years.

Results: Of the 1,500 questionnaires distributed, 1,339 (89\%) were completed. The overall prevalence of nocturnal and diurnal enuresis were $17.5 \%(\mathrm{n}=234)$ and $1.9 \%(\mathrm{n}=25)$, respectively. Although male gender, low age, history of enuresis among parents, low educational level of the parents, deep sleep, increased number of siblings, increased number of people sleeping in the child's room, history of enuresis among siblings, poor school performance and history of recurrent urinary tract infections (UTI) were significantly associated with enuresis, but not with severe enuresis. The percentage of children with enuresis seen by physician for treatment was $17.2 \%$. The most preferred treatment option for enuresis was medications $(59.5 \%)$, whereas alarm treatment was the least preferred (2.4\%).

Conclusions: Our results with enuresis prevalence and associated factors were comparable to other epidemiologic studies from various countries. Furthermore we demonstrated that families in Turkey do not pay sufficient attention to enuresis and most of enuretic children do not receive professional treatment.
\end{abstract}

Key words: Enuresis; family characteristics; prevalence

Int Braz J Urol. 2007; 33: 216-22

\section{INTRODUCTION}

Nocturnal enuresis (NE) can be defined as the involuntary passage of urine during sleep beyond the age of anticipated nighttime bladder control, which is generally accepted as 5 years of age. Nocturnal enuresis is a very common clinical problem in children, especially in boys. Despite the fact that this condition is usually labeled benign, it often leads to considerable emotional distress and concern in affected children and their parents (1). Approximately $15 \%$ of children wet their bed at night when they are 5 years old. There is a spontaneous resolution rate of about $15 \%$ per year; therefore, by the age 15 , only about $1 \%$ of adolescents have a problem with NE (2). The etiology of enuresis is not completely understood. This condition probably has a multifactor etiology. Most studies have consistently found that the risk factors 
for enuresis are male gender, low age, family history of enuresis, divorced parents and deep sleep (3-7). Our aims in this study were to determine the prevalence and associated factors of enuresis in Turkish children and to identify common methods of its management.

\section{MATERIALS AND METHODS}

A prospective cross sectional epidemiological study was performed among primary school children living in Ankara, Turkey. A self-administered questionnaire was prepared for this study and distributed to the parents of 1,500 schoolchildren whom aged 6-12 years. The study consisted of five schools selected randomly. To minimize any embarrassment to children, parents were accessed directly to obtain the information.

The questionnaire consisted of two parts (Figure-1). The first part was designed to investigate associated factors of enuresis, and the second part was planned to determine type and prevalence of enuresis and to identify common methods of its management. The questions in the first part asked about sex, age, education level of parents, other enuretics in the family, presence of other people sleeping in the child's room, sleeping habit, number of siblings, school performance, history of urinary tract infection (UTI) and upper respiratory system infections (URSI). The second part of the questionnaire was completed only by the parents of the enuretic children. The questionnaire in this part asked about the frequency of bed-wetting at night and/or in daytime, wetting after a continuous dry period of $6>$ months and any history medical treatment of enuresis. Enuresis was defined as an episode of bedwetting occurring at least once a month. Primary enuresis was defined as bed-wetting in subjects who have never been dry for an extended period. Furthermore secondary enuresis was defined as the onset of wetting after a continuous dry period of $6>$ months and diurnal enuresis was defined as daytime wetting when the child awakes.

All the data was analyzed with SPSS software for windows (Chicago, IL, USA).
Univariate chi-square test and multivariate logistic regression test was used for the statistical analysis and $\mathrm{p}$ value $<0.05$ was considered as statistically significant.

\section{RESULTS}

Of the 1,500 questionnaires distributed, 1,339 $(89 \%)$ were returned from the parents. The mean age of the children included in the study was $8.8 \pm 1.3$ years. The overall prevalence of nocturnal and diurnal enuresis were $17.5 \%(\mathrm{n}=234)$ and $1.9 \%(\mathrm{n}=25)$, respectively. Nocturnal enuresis was primary in $62.8 \%(\mathrm{n}=147)$ and secondary in $37.2 \%(n=87)$ of the cases. It was particularly more prevalent in boys than in girls, but diurnal enuresis did not reveal a gender bias (Table-1).

Furthermore the prevalence of enuresis decreased with age. Of the 6-year-old children $30.8 \%$ still wetted their beds, while none of those aged 12 years did so. The prevalence of enuresis in males and females according to age group are shown in Table-2.

Several parental factors that are related to enuresis were history of enuresis and low educational level of the parents. These factors were significantly higher in children with enuresis when compared to nonenuretics (Table-3). The rate of male gender, low age, deep sleep, poor school performance, history of enuresis in siblings, increased number of siblings, increased room sharing with other siblings and recurrent UTI were significantly higher in enuretics when compared to non-enuretics (Table-4). We adjusted the data for age and the factors that were related with enuresis were gender, family history of enuresis, deep sleep, parents' educational level and the history of enuresis in siblings (Table-5).

The severities of enuresis for four categories of frequency (every night, 4-6 times per week, 1-3 times per week and 1-2 times per month) were $33.3 \%$, $10.7 \%, 25.6 \%$ and $30.3 \%$, respectively. On the other hand the factors that were significantly related to enuresis were not related to severe enuresis (every night $)(\mathrm{p}>0.05)$.

The percentage of children with enuresis seen by physician for treatment was $17.2 \%$. The treatment 


\section{Part 1}

1. Is your child? Male $\square$ Female $\square$ (Please tick)

2. Child age ___ years

3. Is your child deep sleeper? Yes $\square$ No $\square$

4. How is the school performance of your child? Good $\square$ Moderate $\square$ Fail $\square$

5. Number of siblings. None $\square$ Single $\square 2$ or more $\square$

6. Presence of other people sleeping in the child's room. None $\square 1$ person $\square 2$ or more $\square$

7. History of enuresis in the siblings. Yes $\square$ No $\square$

8. History of recurrent urinary tract infection. Yes $\square$ No $\square$

9. History of upper respiratory tract infection. Yes $\square$ No $\square$

10. Age of the mother; age ___ years.

11. Age of the father; age ____ years.

12. Dead father. Yes $\square$ No $\square$

13. Dead mother. Yes $\square$ No $\square$

14. Working mother. Yes $\square$ No $\square$

15. Working father. Yes $\square$ No $\square$

16. Education level of mother. Primary school or less $\square$ Junior high school or more $\square$

17. Education level of father. Primary school or less $\square$ Junior high school or more $\square$

18. Family history of enuresis.

Mother or father enuretic

Mother and father enuretic

Mother and father non-enuretic $\square$

Part 2

19. Does your child wets his/her bed during nighttime? Yes $\square$ No $\square$

20. What is the frequency of bedwetting of your child?

Every night $\square$ 4-6 times per week $\square$ 1-3 times per week $\square$ 1-2 times per month $\square$

21. Did your child have continuous dry period more than six months? Yes $\square$ No $\square$

22. Did your child experienced bedwetting during daytime? Yes $\square$ No $\square$

23. Did your child treated for bedwetting? Yes $\square$ No $\square$

24. What type of treatment did your child received?

Medications $\square$ waking to void $\square$ wait for maturity $\square$ fluid restriction $\square$ alarm treatment

Figure 1 - Survey questionnaire. 
Table 1 - Prevalence of enuresis.

\begin{tabular}{lrrrrrr}
\hline & N & Boys & \% & N & Girls & Total \\
& & & N & \% \\
\hline Nocturnal enuresis & 130 & 20.1 & 104 & 15.0 & 234 & 17.5 \\
Diurnal enuresis & 13 & 2.0 & 12 & 1.7 & 25 & 1.9 \\
\hline
\end{tabular}

Table 2 - The frequency of nocturnal enuresis in relation to age and gender.

\begin{tabular}{|c|c|c|c|c|c|c|}
\hline \multirow{2}{*}{$\begin{array}{c}\text { Age } \\
\text { (years) }\end{array}$} & \multicolumn{2}{|c|}{ Boys } & \multicolumn{2}{|c|}{ Girls } & \multicolumn{2}{|c|}{ Total } \\
\hline & $\mathbf{n} / \mathbf{N}$ & $\% *$ & $\mathbf{n} / \mathbf{N}$ & $\% *$ & $\mathbf{n} / \mathbf{N}$ & $\% *$ \\
\hline 6 & $4 / 8$ & 3.1 & $-/ 5$ & - & $4 / 13$ & 1.7 \\
\hline 7 & $22 / 99$ & 16.9 & $17 / 98$ & 16.3 & $39 / 197$ & 16.7 \\
\hline 8 & $44 / 174$ & 33.8 & $32 / 221$ & 30.8 & $76 / 395$ & 32.4 \\
\hline 9 & $33 / 178$ & 25.4 & $35 / 180$ & 33.7 & $68 / 358$ & 29.0 \\
\hline 10 & $18 / 96$ & 13.8 & $15 / 98$ & 14.4 & $33 / 194$ & 14.1 \\
\hline 11 & $9 / 67$ & 6.9 & $5 / 81$ & 4.8 & $14 / 148$ & 6.0 \\
\hline 12 & $-/ 25$ & - & -19 & - & $-/ 34$ & - \\
\hline Total & $130 / 647$ & 20.1 & $104 / 692$ & 15.0 & & \\
\hline
\end{tabular}

$n=$ number of enuretic children; $N=$ total number in each age group; $*=$ percentage in enuretic children.

Table 3 - Parental factors that were related to enuresis.

\begin{tabular}{|c|c|c|c|c|c|}
\hline \multirow[t]{2}{*}{ Factors } & \multicolumn{2}{|c|}{ Enuretics } & \multicolumn{2}{|c|}{ Non-enuretics } & \multirow[t]{2}{*}{ p Value } \\
\hline & $\mathbf{N}$ & $\%$ & $\mathbf{N}$ & $\%$ & \\
\hline Working mother & 26 & 112 & 174 & 15.7 & NS \\
\hline Working father & 201 & 874 & 1001 & 90.7 & NS \\
\hline Dead mother & 1 & 0.4 & 6 & 0.5 & NS \\
\hline Dead father & - & - & 2 & 0.2 & NS \\
\hline \multicolumn{6}{|l|}{ Education level of mother } \\
\hline Primary school or less & 194 & 83.3 & 755 & 68.3 & \\
\hline Junior high school or more & 39 & 16.7 & 350 & 31.7 & $<0.001$ \\
\hline \multicolumn{6}{|l|}{ Education level of father } \\
\hline Primary school or less & 169 & 73.5 & 570 & 51.6 & \\
\hline Junior high school or more & 61 & 26.5 & 535 & 48.4 & $<0.001$ \\
\hline \multicolumn{6}{|l|}{ Family history of enuresis } \\
\hline Mother or father enuretic & 72 & 30.8 & 122 & 11.0 & \\
\hline Mother and father enuretics & 33 & 14.1 & 30 & 2.7 & \\
\hline Mother and father non-enuretic & 129 & 55.1 & 953 & 86.2 & $<0.001$ \\
\hline
\end{tabular}

NS = not significant . 


\section{Enuresis in Turkish Children}

Table 4 - The associated factors related to children for enuresis.

\begin{tabular}{|c|c|c|c|c|c|}
\hline \multirow[t]{2}{*}{ Factors } & \multicolumn{2}{|c|}{ Enuretics } & \multicolumn{2}{|c|}{ Non-enuretics } & \multirow[t]{2}{*}{ p Value } \\
\hline & $\mathbf{N}$ & $\%$ & $\mathbf{N}$ & $\%$ & \\
\hline Deep sleeper & 141 & 60.2 & 343 & 31.0 & $<0.001$ \\
\hline \multicolumn{6}{|l|}{ Number of siblings } \\
\hline None & 20 & 8.5 & 154 & 13.9 & \\
\hline Single sibling & 101 & 43.2 & 520 & 47.1 & 0.003 \\
\hline 2 or more & 113 & 48.3 & 431 & 39.0 & \\
\hline \multicolumn{6}{|l|}{ Room sharing } \\
\hline None & 43 & 18.4 & 298 & 27.0 & \\
\hline 1 person & 127 & 54.3 & 556 & 50.3 & 0.009 \\
\hline 2 or more & 64 & 27.4 & 251 & 22.7 & \\
\hline History of enuresis in the siblings & 117 & 50.0 & 248 & 22.4 & $<0.001$ \\
\hline \multicolumn{6}{|l|}{ School performance } \\
\hline Good & 83 & 35.5 & 550 & 49.8 & \\
\hline Moderate & 99 & 42.3 & 445 & 40.3 & $<0.001$ \\
\hline Fail & 52 & 22.2 & 110 & 10.0 & \\
\hline Recurrent UTI & 43 & 18.4 & 143 & 12.9 & 0.037 \\
\hline Recurrent URSI & 54 & 23.1 & 233 & 21.1 & NS \\
\hline
\end{tabular}

$U T I=$ urinary tract infection; $U R S I=$ upper respiratory system infection; $N S=$ not significant.

Table 5 - Age adjusted data with multivariate analysis.

\begin{tabular}{lccccc}
\hline & $\begin{array}{c}\text { Coefficient of } \\
\text { Regression }\end{array}$ & p Value & $\begin{array}{c}\text { Odd Ratio } \\
\text { (OR) }\end{array}$ & Lower* & Upper* \\
\hline Gender & 0.45 & 0.007 & 1.57 & 1.13 & 2.17 \\
Education level of father & 0.77 & $<0.001$ & 2.15 & 1.51 & 3.06 \\
Family history of enuresis & & & & & \\
$\quad$ Parents non-enuretic & 1.27 & $<0.001$ & reference & & 5.22 \\
$\quad$ Mother or father enuretic & 2.05 & $<0.001$ & 7.56 & 4.42 & 11.83 \\
$\quad$ Mother and father enuretics & 1.10 & $<0.001$ & 3.00 & 2.17 & 4.16 \\
Deep sleeper & & & & & \\
School performance & & & reference & & \\
$\quad$ Good & 0.11 & 0.540 & 1.12 & 0.78 & 1.61 \\
$\quad$ Moderate & 0.67 & 0.005 & 1.95 & 1.22 & 3.11 \\
$\quad$ Fail & 0.99 & $<0.001$ & 2.68 & 1.93 & 3.73 \\
Siblings' history of enuresis & & &
\end{tabular}

$*=95 \%$ confidence interval for $O R$.

modalities offered to these children were medications $(59.5 \%)$, waking to void $(26.2 \%)$, wait for maturity $(7.1 \%)$, fluid restriction (4.8\%) and alarm treatment $(2.4 \%)$.

\section{COMMENTS}

Enuresis is one of the common disorders in pediatric population. In most countries the prevalence 
of enuresis among 6-11 years old children is reported as $1.4-28 \%(3-5,8)$. Likewise in the present study we obtained the prevalence of enuresis in children at 6-12 years of age as $17.5 \%$. In previous studies reported from different Turkey provinces, the prevalence of enuresis was reported as $11.5-13.7 \%$, which was lower than our study's prevalence $(6,7,9)$.

Previous studies demonstrated that the prevalence of enuresis tended to decrease with increasing age, and it was more common in boys rather than girls. Similarly in the present study $30.8 \%$ of the children were wetting their beds at age 6 whereas none of them were wetting their beds at age 12. However a small number of children in the age group 6 and 12 ( $\mathrm{n}=13$ and 34 respectively) was the limitation of our study. Furthermore the prevalence of enuresis in boys and girls were $20.1 \%$ and $15 \%$ respectively. In another study which was conducted by Lee et al reported the prevalence of enuresis at age 7 as $20.4 \%$ and this rate decreased to $5.6 \%$ by age 12 (4).

The parental factors that were significantly related to the prevalence of enuresis in our study were history of enuresis and the low educational level of the parents. The rate of history of enuresis in the parents was $30.8 \%$ in the enuretic children whereas this rate was only $11 \%$ in the non-enuretic children. Furthermore previous studies reported the prevalence of family history in enuretic children as $22-48 \%$ $(3,7,9,10)$ Twin studies also support a genetic basis for enuresis. The concordance rate is much higher in monozygotic twins (36\%) (11). Danish researchers were the first to report an unidentified enuresis gene (ENUR1) in chromosome region 13q (12). Later studies have also shown linkage to chromosome 12q and chromosome $22(13,14)$.

Corresponding with the previous studies, in our study the factors that are significantly related to enuresis were male gender, low age, deep sleep, poor school performance, history of enuresis in the siblings, increased number of siblings, room sharing and recurrent UTI. However URSI and the behavioral profile of the children were not related with enuresis. Not even previous studies could demonstrate a specific behavioral profile in enuretic children $(1,15)$. On the other hand further reported factors that significantly related to enuresis were divorced parents, low birth rate, growth retardation, constipation, bronchial asthma, allergy and liquid intake before go to sleep $(3,5,16,17)$.

We defined severe enuresis as bed wetting every night $(33.3 \%)$ which did not relate to any of the factors stated above. However Chang reported that deep sleep is significantly related with bed wetting more than three times a week (5). Watanabe and Kawauchi showed that the arousal centre was activated to turn deep sleep into light sleep when the bladder was distended (18). They also found that a disturbance in this arousal system might result in sustained deep sleep and hence cause enuresis.

In the present study only $17.2 \%$ of the children were seen by a physician and previous series reported as $11-34 \%(4,6,9)$. These low rates demonstrate that most of the children with enuresis were not treated. Oge and associates from Turkey reported that the families mostly choose the traditional methods in order to treat enuresis (6). On the contrary in the present study most of the children $(61.9 \%)$ were treated with professional methods provided by physicians. On the other hand the use of alarm treatment was significantly lower when compared to medications (2.4\% vs. 59.5\%). However at present the use of alarm for enuresis treatment is the preferred treatment modality because of high success rate and low relapses (19).

\section{CONCLUSIONS}

Our results with enuresis prevalence and associated factors which were male gender, low age, history of enuresis among parents, low educational level of the parents, deep sleep, increased number of siblings, increased number of people sleeping in the child's room, history of enuresis among siblings, poor school performance and history of recurrent UTI, were comparable to other epidemiologic studies from various countries. However severe enuresis did not relate to any of the mentioned factors. We documented that most 
of the children with enuresis were not treated and the families in Turkey do not have adequate attention about enuresis and most of the enuretic children do not receive professional treatment.

\section{CONFLICT OF INTEREST}

None declared.

\section{REFERENCES}

1. Moffatt ME: Nocturnal enuresis: psychologic implications of treatment and nontreatment. J Pediatr. 1989; 114: 697-704.

2. Forsythe WI, Redmond A: Enuresis and spontaneous cure rate. Study of 1129 enuretis. Arch Dis Child. 1974; 49: 259-63.

3. Kalo BB, Bella H: Enuresis: prevalence and associated factors among primary school children in Saudi Arabia. Acta Paediatr. 1996; 85: 1217-22.

4. Lee SD, Sohn DW, Lee JZ, Park NC, Chung MK: An epidemiological study of enuresis in Korean children. BJU Int. 2000; 85: 869-73.

5. Chang P, Chen WJ, Tsai WY, Chiu YN: An epidemiological study of nocturnal enuresis in Taiwanese children. BJU Int. 2001; 87: 678-81.

6. Oge O, Kocak I, Gemalmaz H: Enuresis: point prevalence and associated factors among Turkish children. Turk J Pediatr. 2001; 43: 38-43.

7. Gumus B, Vurgun N, Lekili M, Iscan A, Muezzinoglu T, Buyuksu C: Prevalence of nocturnal enuresis and accompanying factors in children aged 7-11 years in Turkey. Acta Paediatr. 1999; 88: 1369-72.

8. Bower WF, Moore KH, Shepherd RB, Adams RD: The epidemiology of childhood enuresis in Australia. Br J Urol. 1996; 78: 602-6.
9. Serel TA, Akhan G, Koyuncuoglu HR, Ozturk A, Dogruer $\mathrm{K}$, Unal S, et al.: Epidemiology of enuresis in Turkish children. Scand J Urol Nephrol. 1997; 31: 537-9.

10. Hogg RJ: Genetic factors as predictors for desmopressin treatment success. Scand J Urol Nephrol Suppl. 1997; 183: 37-9.

11. Bakwin H: Enuresis in twins. Am J Dis Child. 1971; 121:222-5.

12. Eiberg H, Berendt I, Mohr J: Assignment of dominant inherited nocturnal enuresis (ENUR1) to chromosome 13q. Nat Genet. 1995; 10: 354-6.

13. Arnell H, Hjalmas K, Jagervall M, Lackgren G, Stenberg A, Bengtsson B, et al.: The genetics of primary nocturnal enuresis: inheritance and suggestion of a second major gene on chromosome 12q. J Med Genet. 1997; 34:360-5.

14. Eiberg H: Total genome scan analysis in a single extended family for primary nocturnal enuresis: evidence for a new locus (ENUR3) for primary nocturnal enuresis on chromosome 22q11. Eur Urol. 1998; 33 Suppl 3: 34-6.

15. Couchells SM, Johnson SB, Carter R, Walker D: Behavioral and environmental characteristics of treated and untreated enuretic children and matched nonenuretic controls. J Pediatr. 1981; 99: 812-6.

16. Rawashdeh YF, Hvistendahl GM, Kamperis K, Hansen MN, Djurhuus JC: Demographics of enuresis patients attending a referral centre. Scand J Urol Nephrol. 2002; 36:348-53.

17. Cher TW, Lin GJ, Hsu KH: Prevalence of nocturnal enuresis and associated familial factors in primary school children in taiwan. J Urol. 2002; 168: 1142-6.

18. Watanabe $\mathrm{H}$, Kawauchi A: Locus coeruleus function in enuresis. Scand J Urol Nephrol Suppl. 1999; 202: 14-7.

19. Jensen N, Kristensen G: Frequency of nightly wetting and the efficiency of alarm treatment of nocturnal enuresis. Scand J Urol Nephrol. 2001; 35: 357-63.

Accepted after revision:

November 23, 2006

Correspondence address:

Dr. Cuneyt Ozden

Cevizlidere Mah. 14. Cad. Balgat 12/25

Ankara, 06100, Turkey

E-mail: cuneytozden@hotmail.com 